\title{
LEVELS OF LEAD AND CADMIUM IN HAIR AND SALIVA OF SCHOOL CHILDREN IN CERES DISTRICT, SOUTH AFRICA.
}

\author{
Ogboko $B^{1 *}$, Fisher $D^{1}$ and $R$ Swart $^{1}$
}

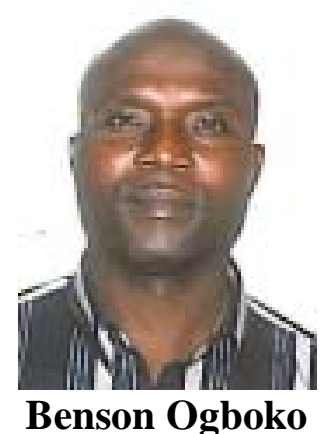

Corresponding author email: bogboko@uwc.ac.za

${ }^{1}$ University of the Western Cape, Bellville. South Africa. 


\section{ABSTRACT}

The objective of this study was to investigate the presence of cadmium $(\mathrm{Cd})$ and lead $(\mathrm{Pb})$ in the hair and saliva of schoolchildren $(\mathrm{n}=265)$ in Ceres district, rural and agricultural Town. The role of other factors, such as the socio-economic status, and anthropometric data of the children were also investigated including levels of elements in water, common foods and cultivated vegetables.

The results showed high mean levels of $\mathrm{Pb}$ in both hair $(1.17 \pm 0.99 \mu \mathrm{g} / \mathrm{kg})$ and saliva $(1.07 \pm 1.31 \mu \mathrm{g} / \mathrm{L})$, when compared with the reference mean $(<0.55 \mu \mathrm{g} / \mathrm{kg}$ and $<1.0$ $\mu \mathrm{g} / \mathrm{L})$ respectively. The mean level of $\mathrm{Cd}$ in hair $(0.95 \mu \mathrm{g} / \mathrm{kg} \pm 044)$ was also high but within the reference value $(<1.55 \mu \mathrm{g} / \mathrm{kg})$. Likewise, $\mathrm{Cd}$ in saliva with a mean concentration of $0.67 \pm 0.48 \mu \mathrm{g} / \mathrm{L}$ was within the reference values $(0.4-2.25 \mu \mathrm{g} / \mathrm{L})$. Both proportions fall within the threshold of $0.3 \%$ lead in hair $(\mathrm{Pb}<0.55 \mu \mathrm{g} / \mathrm{kg})$ and cadmium in hair $(\mathrm{Cd}<1.55 \mu \mathrm{g} / \mathrm{kg})$.

The study also showed the presence of both elements in water, common food and cultivated vegetables. The socio-economic status and anthropometric data did not have a significant effect on both elements. Considering the environmental nature of Ceres as a rural agricultural town with such high levels of these elements in the learners and other elements and knowing that the half life of most heavy elements is between $20 \mathrm{yrs}$ and $40 \mathrm{yrs}$, one cannot underestimate the potential health risk, resulting in the none absorption of other essential elements like iron and zinc, resulting in learning difficulties and nutritional deficiencies in later years.

These results support most findings that heavy metal elements can be found in hair and saliva. However, the source of these elements is unknown, but there are indications that environmental factors might be responsible. These findings need to be further investigated to ascertain the source, potential impact of these findings, and the possible role of food fortification in reducing negative effects.

Keyword: Hair, saliva, cadmium, lead, children. 


\section{INTRODUCTION}

Virtually all minerals at sufficient levels of exposure can produce adverse health effects [1]. The use of a noninvasive (e.g. hair and saliva) approach to measure heavy elements is now seen as an authentic way of investigating heavy element profiles in humans, due to its ability to present long-term deposition (hair), and saliva representing cellular levels (recent element levels).

The harmful effect of lead on child development can occur without clinical symptoms and might not present any abnormality during routine test [2]. Factors that might modify the risk of lead toxicity include pre-existing disease affecting relevant target organs (such as diabetic nephropathy or border hypertension), nutritional deficiencies (particularly of dietary cations such as iron and calcium), ethnicity and age [3]. Higher levels or chronic exposure of lead will result in more severe symptoms such as kidney and nervous system damage [4].

Concentrations of lead and other heavy metals in the hair provide an accurate and relatively permanent record of exposure, and there is a strong correlation between concentration in hair and concentration in internal organs [5]. Findings of other researchers showed similar results $[6,7]$. Lead in hair may be a reflection of external contamination rather than internal lead and in some cases laboratory analysis is not standardized [6] and cannot reflect the exact level of contamination. The binding of endogenous trace elements in the hair structure is assumed to be biologically inert and irreversible $[8,9]$.

Hence, blood lead level tests will complement the noninvasive methods, which use hair and saliva analysis in heavy elements analysis and assist in investigating the potential contribution of environmental neurotoxicant exposure in childhood psychiatric morbidity [10] due to its ability to look at the long-term and recent effect of element contamination.

Saliva analysis provides a profile of the biologically active compounds at cellular levels and is therefore a representation of what is clinically relevant. Blood analysis provides a profile of the compounds as they travel through circulation, mostly bound to protein. Wang et al $[11,9]$ shows that experiences from saliva analysis enable one to predict, diagnose or prevent many health problems and diseases. Studies carried out by Gonzalez et al. [12] also emphasized the potential for monitoring recent exposure to ambient pollutants, since circulating levels of certain polluting chemicals can be transported into salivary glands and secretions.

Heavy elements like lead $(\mathrm{Pb})$ and cadmium $(\mathrm{Cd})$ in the human body normally comprise, less than $0.01 \%$ of body weight. Most heavy elements are usually absorbed into the human body either by ingestion, inhalation, or absorption through skin contact [13]. Lead can be found naturally in the earth crust alongside sulfide ores of zinc and copper. Other sources of lead are from pottery glaze, lead batteries, lead paints in old houses and gasoline (before the use was banned), lead solder in water 
pipes and lead polluted air, food, water, dust and soil. Cadmium is present in vehicle tires and consequently in the particles resulting from tire wear. Cadmium is also emitted in tobacco smoke, by plants from fertilizers, sewage sludge, manure and atmospheric deposition. [13, 14].

Lead crosses the blood-brain barrier. In adults this may result in lead encephalopathy, mental retardation and anemia [15]. A Center for Disease Control and Prevention, 2005 report states that, the blood-brain developed in children will be more susceptible to lead exposure and suffer brain damage if exposed to lead contaminations. Long-term high cadmium exposure has been reported to cause skeletal damage. The itai-itai (ouch-ouch) disease which is the combination of osteomalacia and osteoporosis [16], is a result of cadmium contamination. High cadmium intake can lead to low bone mineral density (osteoporosis), fractures $[17,18]$ and cardiovascular disease [19].

\section{BACKGROUND}

Heavy elements contamination remains a major hindrance to nutritional intervention [20] and effective utilization of nutrients [21, 4]. Food nutrient values have reduced over the years due to soil degradation resulting from constant cultivation [22].

The Ceres area of the Western Cape is an agricultural town and includes communities that fully represent the South African economic spectrum and population diversity.

\section{AIM OF THE STUDY}

The purpose of this study was to investigate the presence of lead and cadmium in saliva and hair of school children.

\section{METHODOLOGY}

\section{Study design}

This study aimed to assess, the levels of lead and cadmium in hair and saliva. This technique is widely used for the determination of trace elements in matrices, especially in human biological materials. We analyzed lead and cadmium in grade one learners in primary schools in Ceres, Western Cape, South Africa.

Prior to data collection, parents of the children under investigation were asked whether special shampoos, relaxers or cream were used on their hair, and also if they had any direct contact with objects that might increase their venerability to heavy element contamination. Where the answer was a yes, the samples collected were discarded and not included in the analyses.

\section{Study population and study sample}

The study population consisted of grade one learners attending the six primary schools in Ceres in 2003 and 2004. The study sample was selected randomly from each school, using random number tables, with proportionate representation of each 


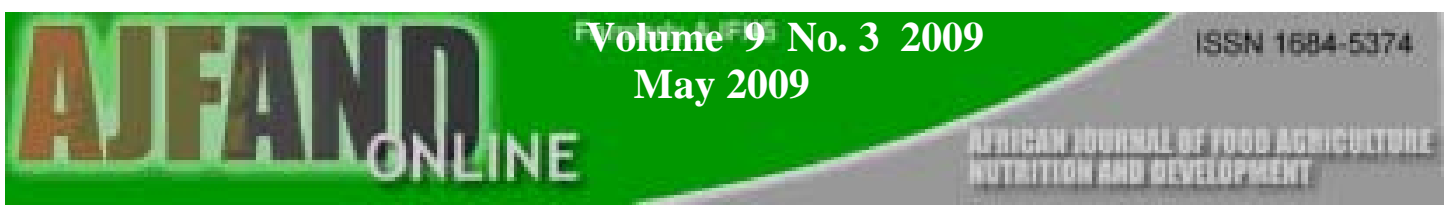

school. A total number of 265 learners were included in this study (Table 1). Following informed consent, $62 \%$ of those asked to participate signed consent forms

\section{Data collection}

Sample and data collection took place during school hours over a period of one week towards the end of each year. Samples were prepared for analyses within one week of sample collection.

\section{Determination of lead and cadmium in hair and saliva samples}

The determination of lead and cadmium in hair and saliva, using the conventional aqua regia digestion procedure, consisted of dissolving samples in a 3:1 mixture of $\mathrm{HCl}$ and $\mathrm{HNO}_{3}$ and digesting on a hotplate for $3 \mathrm{hrs}$ [23]. A photometric method was used in analyzing the digested samples using an atomic absorption spectrophotometer (AAS) (Unicam AAS Type solar) [24, 25].

Spectrophotometry: About $5 \mathrm{~mL}$ of digested samples were analyzed using the AAS at a wavelength most suitable to the particular element being analyzed with minimum or no interference.

Precaution was taken throughout the experiments to avoid contamination of the samples, reagents and chemicals used. The samples were weighed accurately. Extra care was taken to avoid errors in reading caused by acid interference, common with the aqua regia method. In order to obtain reproducible results, it was important that we maintained constant optimal aspiration and furnace conditions. All machine readings were repeated twice.

HAIR: Approximately $0.5 \mathrm{~g}$ of hair, from the back of the head close to the neck, was obtained from each learner using a sterilized stainless steel scissors. The scissors were cleaned with ethanol after each hair collection.

Hair samples were washed with non-ionic detergent and rinsed with distilled water, oven dried for 4 days at $60-70^{\circ} \mathrm{C}$ and stored in an airtight plastic bag. $0.25 \mathrm{~g}$ wellmixed dried hair was weighed into a beaker and digested in $12 \mathrm{~mL}$ of aqua regia $\left({ }^{1} / 3\right.$ $\mathrm{HNO}_{3}$ and $3 / 4 \mathrm{HCl}$ ) acid, heated in a heated Gerhardt (Trace metal digestion units, DIN 38414) digestion block. The maximum digestion temperature was $120^{\circ} \mathrm{C}$ and to avoid loss of materials each beaker had a glass lid. Digestion continued until a clear colorless solution was obtained. Each sample took 2-3 hrs to digest. The clear solution obtained was allowed to cool, filtered with Whatman no. 42 paper, and diluted to a final volume of $100 \mathrm{~mL}$ with double deionized distilled water (DDW) [26]. This solution was stored in a plastic container until analysis using the AAS was performed.

SALIVA: A minimum volume of 5.0mL mixed saliva was collected from the learners into a detergent washed polypropylene vial by direct collection. The samples were checked for food and blood or nasal discharge contamination and contaminated samples were discarded. Four saliva samples that did not have matching hair samples were discarded. The mixed saliva was then frozen and stored in a freezer at $0^{\circ} \mathrm{C}$ to $4^{\circ} \mathrm{C}$.

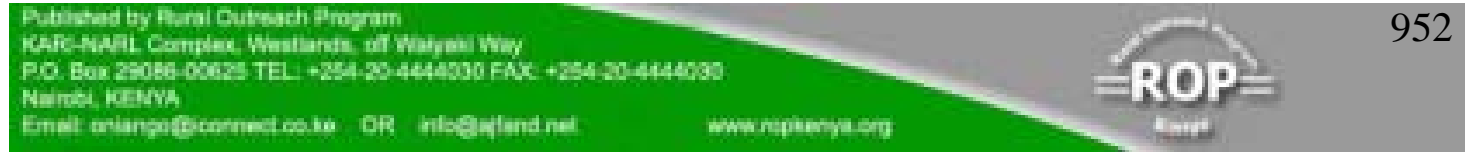


Prior to sample preparation, the saliva samples were defrosted and allowed to equilibrate to room temperature before being rechecked for any traces of contaminants. Five $\mathrm{mL}$ of saliva was then measured into a beaker and $20 \mathrm{~mL}$ of $2 \%$ nitric acid $\left(\mathrm{HNO}_{3}\right)$ was added. This solution was filtered with Whatman no. 42 filter paper into a volumetric flask and diluted to a final volume of $100 \mathrm{~mL}$ with DDW [26]. The $100 \mathrm{~mL}$ solution was then stored in a plastic container until analysis with an AAS for cadmium and lead was done.

\section{ETHICAL CONSIDERATIONS}

The Senate Research committee of the University of the Western Cape provided ethical approval for this study (SHD of 2004/6). The participation of learners was voluntary following informed consent by parents or guardians. The participants were free to terminate participation at their convenience. Confidentiality of the data collected and subsequent findings were assured by using only code numbers for each participant.

\section{STATISTICAL ANALYSIS}

The data were analyzed using SAS version 8.12 [27]. The results are presented as mean, standard deviations, and Pearson Correlation Coefficients between lead and cadmium in hair and saliva. The $\mathrm{p}$ values of $<0.01$ were considered statistically significant.

\section{RESULTS}

Sixty-two percent of the study sample consented to participation. This number represented 265 of the total number of 426 grade one learners over the study period (Table 1) with a male: female ratio $1: 1$. The mean age was $7.73 \pm 0.60 \mathrm{yrs}$. The average weight and height of the children were $21.93 \pm 4.8 \mathrm{~kg}$ and $118.69 \pm 7.2 \mathrm{~cm}$, respectively. The median household income contributors were 2 persons and that of income was R250-R999 per month (Table 2).

Table 3 shows the total number of samples collected from each participant, the average levels of lead and cadmium in the hair and saliva samples and their reference values. There were high levels of lead in both hair $(1.17 \pm 0.99 \mu \mathrm{g} / \mathrm{kg})$ and saliva $(1.07$ $\pm 1.31 \mu \mathrm{g} / \mathrm{L})$, when compared with the standard values of $<0.55 \mu \mathrm{g} / \mathrm{kg}$ and $<1.0 \mu \mathrm{g} / \mathrm{L}$, respectively, for hair and saliva. The level for cadmium in hair $(0.95 \pm 0.44 \mu \mathrm{g} / \mathrm{kg})$ is also high with $56 \%$ of them above average although the mean was within the tolerable limits in the human body $(1.55 \mu \mathrm{g} / \mathrm{kg})$. Likewise, $\mathrm{Cd}$ in saliva had a mean concentration of $(0.67 \pm 0.48 \mu \mathrm{mol} / \mathrm{L})$ [1].

The Pearson correlation coefficient showed a significant correlation $(\mathrm{p}<0.01)$ between cadmium in hair and saliva, and lead in hair and saliva ( $\mathrm{p}<0.05)$. In other results levels of lead and cadmium were found in water and cultivated vegetable, although levels were high but within the range of reference values.

Other factors like weight and height showed no significant difference with gender, although there was a significant difference in the socio-economic status of children 


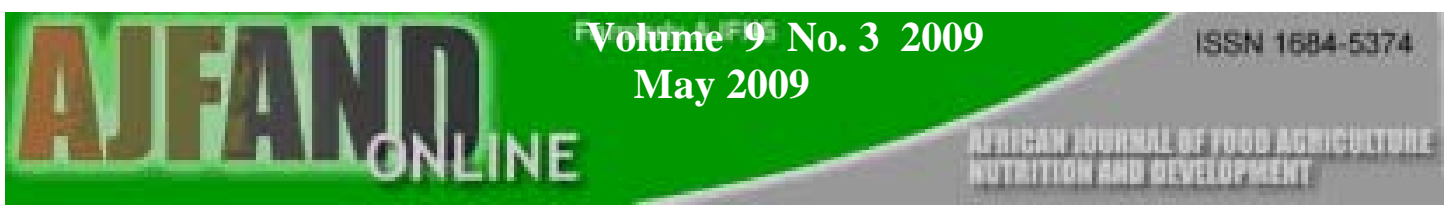

but these did not influence the levels of lead and cadmium in both hair and saliva of the learners investigated.

\section{DISCUSSION}

The results obtained from this survey compare with the findings by Marlowe [5] that the concentration of lead and other heavy metals in the hair provide an accurate and relatively permanent record of exposure. Furthermore, there is a strong correlation between the concentration in hair and saliva (internal organs) [6]. These results also tend to agree with findings of other researchers [7,8].

The lead and cadmium in hair and saliva showed a strong presence of these heavy elements. The results demonstrate the reliability of the aqua regia method for heavy element analysis although concentrations were high which may be attributed to various factors like acid interference, external contaminations (although a blank was used as a precaution), and technical errors. Comparing hair and saliva, with urine analysis, simplicity of matrix, relatively high concentration of trace element, easier sample gathering, transfer and storage should be considered [28, 29].

Generally, a high concentration of one element in hair indicates that the person is contaminated by that element. However, since blood, saliva or urine analysis may exhibit different concentrations even though the sample is gathered at the same time as the hair, the analytical results for the hair analyzed should be considered carefully. The lack of a standard procedure for sample collection, washing, treatment and analytical quality control protocol arouses considerable resistance towards the reliability of hair analysis [30]. The aqua regia method of analysis is susceptible to acid interference, which makes it unreliable if used alone. The multiple analyses like the use of saliva and blood is therefore required especially in rural communities.

The aim of this pilot study was to investigate the presence of these elements, as further research and since this method has never been used a reference point is needed. Hair and saliva analysis can indicate either long-term or recent deposition of these elements in the human body, judging from the geographical location of Ceres.

The results have shown the relative ease with which saliva can be collected and analyzed, and confirm the relationship between salivary trace element concentrations and dietary intake as reported in literature [31]. The cost-effectiveness of the method when compared to blood analysis in disadvantaged communities sparked our interest in the potential value of saliva as an assessment index for trace elements [32].it justifies the findings of other researchers who have shown the advantage of analyzing substances using samples obtained by noninvasive methods. This finding also sheds more light on the long-term effects of lead contamination in children. Some studies report an association between increased exposure to inorganic lead and parents' or teachers' rating of children's behavior, particularly using such indices as poor attention, distractibility, impulsiveness and non-persistence [33, 34]. 
Lead is known to easily dissolve in blood and can be transported to non-active tissues like hair, nails and bones for storage (28). High levels of lead in women's bone at the time of childbirth corresponded to lower birth weight, reduced head circumference, and birth length [35]. Hence, the study of blood lead levels will complement hair and saliva analysis in order to ascertain the exact levels of contamination.

The role of external factors responsible for the high levels of these elements found in children cannot be undermined. Hence, the influence of the environment is very significant (e.g. locally cultivated vegetables, paint from houses and toys, shampoos and creams on children's hair, culture and parents involvement). The influence of other factors like weight, height and age showed no significant effect. The heavy element concentration in children investigated was not influenced by environmental factors and, likewise, the socio-economic status did not play any significant role. These could be attributed to the lifestyle of the people.

\section{CONCLUSION}

The results of this survey suggest the presence of elevated heavy elements in both hair and saliva, justify the use of the noninvasive method of sample collection. High levels of lead ands cadmium in hair and saliva above reference levels was found in school children in Ceres. The implication of these high levels may not be visible currently but there is a high possibility of long-term accumulation of these heavy elements which can result to health hazards later in life. Since the results of this study suggest no influence of anthropometrics and socio-economic on the concentration of these elements, we cannot rule out the influence of food, water and cultivated vegetables since the children's lifestyle centers on the culture of food that is commonly eaten by a majority of the population in Ceres. Other factors that need to be looked at are the land formations and agricultural activities around Ceres, as these might contribute to the presence of these elements.

Although the conclusion is speculative, the findings may offer an avenue for further research. It is worth pointing out, that while undertaking research of this nature may be informative, the current state of knowledge for the practical implications of clinical management is limited.

The reliability of trace element concentrations in hair and saliva as indices of trace element status could be markedly enhanced when combined with other related indices measured simultaneously. Hence, the use of blood and other parameters should be encouraged. In a situation where the toxic element is not directly responsible as the cause of any particular illness, it is possible that it may still have a role in the cause of related disorders. The interactions of trace elements in the body may have a dramatic impact on the utilization of other nutrients. Be it essential/non essential or macro/micro nutrients, heavy element binding ability make it possible to displace lower elements in the periodic table and rendering them unavailable in cell structures. 


\section{LIMITATIONS}

The findings in this report are subject to some limitations, which include the wide range of results obtained from the use of the aqua regia method known to be susceptible to acid interference. Although parents of children were asked to give information on the use of creams, shampoo and other chemicals on the children's hair, there are possibilities of foreign substance interference. This report provides a snapshot on how information on element contaminations can be collected from children within a short time and is one way of monitoring the state or progress of children affected by contamination. Finally, there is an indication that the presence of these elements might have resulted from prolonged environmental exposure to these elements.

\section{ACKNOWLEDGEMENT}

I acknowledge the following person for their immense contribution towards the successful completion of this paper; Prof. Lincoln Raitt, Lilburne Cyster, staff and students of Human ecology and Dietetic department. 
Table 1: $\quad$ Description of study sample.

\begin{tabular}{|c|c|c|c|c|c|}
\hline Year & $\begin{array}{l}\text { Total } \\
\text { Number of } \\
\text { learners in } \\
\text { six schools }\end{array}$ & $\begin{array}{l}\text { Number of } \\
\text { learners } \\
\text { selected for } \\
\text { inclusion }\end{array}$ & $\begin{array}{l}\text { Number of learners } \\
\text { included in survey } \\
\text { (consent received }+ \\
\text { present on day of } \\
\text { data collection) }\end{array}$ & $\begin{array}{l}\text { Proportion } \\
\text { of selected } \\
\text { learners } \\
\text { who } \\
\text { participated }\end{array}$ & $\begin{array}{l}\text { Response } \\
\text { ratio (\%) of } \\
\text { Girls/Boys }\end{array}$ \\
\hline 2003 & 544 & 200 & 115 & $60.0 \%$ & $43 / 57$ \\
\hline 2004 & 688 & 226 & 150 & $64.5 \%$ & $54 / 46$ \\
\hline Total & 1232 & 426 & 265 & $62.3 \%$ & $\begin{array}{c}49 / 51 \\
\text { Ratio } 1: 1\end{array}$ \\
\hline
\end{tabular}

Table 2: $\quad$ Socio-economic characteristics of learners.

\begin{tabular}{|c|c|c|c|c|c|c|}
\hline & $\begin{array}{c}\text { Mean } \\
\text { Age of } \\
\text { participants }\end{array}$ & Weight & Height & $\begin{array}{c}\text { Ave numbers of } \\
\text { persons }\end{array}$ & $\begin{array}{c}\text { Household } \\
\text { Income per } \\
\text { month }\end{array}$ \\
\hline $\begin{array}{c}\text { Phase } \\
\text { One }\end{array}$ & 2003 & 7.60 & 20.46 & 118.71 & $(2-3)$ & $* *$ \\
\hline & 2004 & 7.84 & 22.48 & 118.62 & $(2-3)$ & $\begin{array}{c}(\mathrm{R} 250- \\
\text { R999) }\end{array}$ \\
\hline & Total & $\begin{array}{c}7.73 \\
\pm 0.60\end{array}$ & $\begin{array}{c}21.93 \\
\pm 4.82\end{array}$ & $\begin{array}{c}118.69 \\
\text { R999 })\end{array}$ \\
\hline
\end{tabular}

*Median No. of people contributing to household income, **Average family wages range per month in

Rands is (R 250 - R999) per month 
Table 3: $\quad$ Lead and cadmium in hair and saliva samples.

\begin{tabular}{|c|c|c|c|c|c|c|c|c|}
\hline & & & \multicolumn{6}{|c|}{ Levels of trace elements in hair and saliva samples } \\
\hline \multirow[t]{2}{*}{$\begin{array}{l}\text { paramet } \\
\text { ers }\end{array}$} & $\begin{array}{c}\text { Trace } \\
\text { element }\end{array}$ & $\begin{array}{c}\text { No. Of } \\
\text { Children } \\
\text { (n) }\end{array}$ & $\begin{array}{c}\text { Trace } \\
\text { Element } \\
\text { index } \\
\text { Concentr } \\
\text { ation. } \\
\end{array}$ & $\begin{array}{c}\text { Ref. } \\
\text { standard } \\
\text { Scale }\end{array}$ & \multicolumn{3}{|c|}{$\begin{array}{c}\% \text { within standard range, below } \\
\text { and above }\end{array}$} & $\begin{array}{l}\text { Standard } \\
\text { Deviation }\end{array}$ \\
\hline & $*$ & $\mathbf{N}$ & & $* *$ & Within & Below & above & \\
\hline \multirow[t]{2}{*}{ Hair } & $\begin{array}{l}\text { Lead } \\
\mathrm{ug} / \mathrm{kg}\end{array}$ & 193 & 1.17 & $<0.55$ & & 24 & 76 & 0.99 \\
\hline & $\begin{array}{c}\text { Cadmium } \\
\text { ug/kg }\end{array}$ & 193 & 0.95 & $<0.95$ & & 38 & 62 & 0.44 \\
\hline \multirow[t]{2}{*}{ Saliva } & $\begin{array}{l}\text { Lead } \\
\mathrm{mol} / \mathrm{I}\end{array}$ & 249 & 1.07 & $<1.0$ & & 48 & 52 & 1.31 \\
\hline & $\underset{\mathrm{mol} / \mathrm{l}}{\text { Cadmium }}$ & 249 & 0.67 & $0.4-2.25$ & 68 & 22 & 10 & 0.44 \\
\hline
\end{tabular}

${ }^{*} \mathrm{Hr} \_\mathrm{Pb}=$ Hair lead, $\mathrm{Hr} \_\mathrm{Cd}=$ Hair cadmium, Sl_Pb = Saliva lead, Sl_Cd = Saliva cadmium, $\left({ }^{* *}\right) \mathrm{Ref}$ range. [1], $\mathrm{N}=$ number of children involved in each analysis. 


\section{REFERENCES}

1. Torra M, Robamilaus M, Cobella I Human exposure to metal. Some factor influencing the metal concentrations. Trace Element and Electrolytes 2002: 1926.

2. Cheng Y, Schwartz J, Sparrow D, Aron A, Weiss ST, Hu H Bone lead and blood lead levels in relation to baseline blood pressure and the prospective development of hypertension. In: The Normative aging study. Am J. Epidemiol. 2001; 153: 164-171.

3. Centre for Disease Control Report Lead poisoning in Young Children. (A statement by the Center for Disease Control and Prevention) August 2005. Atlanta. CDC, 2005.

4. IARC. Cadmium and cadmium compounds. In: Beryllium, Cadmium, Mercury and Exposure in the Glass Manufacturing Industry. IARC Monographs on the Evaluation of Carcinogenic Risks to Humans, vol. 58. Lyon: International Agency for Research on Cancer 1993, pp 119-237.

5. Marlowe M Lead and cadmium burdens among mentally retarded children and children with borderline intelligence Am. J. Ment. Defic. 1983; 87: 477 - 483.

6. Hayes RB The carcinogenicity of metals in humans. Cancer Causes Control 1997: 8:371-385.

7. Zheng $\mathbf{W}$ Toxicology of choroid plexus: special reference to metal-induced neurotoxicities. Microsc Res Tech 2001: 52:89-103.

8. Bellinger D Future directions of Neurological studies of environmental Neurotoxicants, Neurotoxicology. 2001: 22:645-56.

9. Wang D, Du X, Zheng W Alteration of saliva and serum concentrations of manganese, copper, zinc, cadmium and lead among career welders. Toxicol Lett. 2008 Jan 4; 176(1):40-7.

10. Abdullahi F, Saira A Toxic elements in the hair of children with autism. Autism 2005, July 9(3):290-8.

11. Labadarios D, Steyn N, Macintyre U, Swart R, Gericke G, Huskission J, Dannhauser A, Voster HH, Nesamvuni AE The National Food Consumption Survey (NFCS) - Children aged 1-9 years, South Africa 1999. Part 1 Methodology, socioeconomic and Anthropometric Data. Medical Update, 37, April 2001.

12. Gonzalez. M, JA Banderas, A Baez, $\mathbf{R}$ Belmont Salivary lead and cadmium in a young population residing in Mexico City. Toxicology Letters. Volume 93, Issue 1, 19 September 1997, pp 55-64. 
13. WHO. Technical Report Series No 940. Evaluation of certain food additives and contaminants (sixty-seventh report of Joint FAO/WHO Committee on food additives), 2007.

14. World Health Organization (WHO). Environmental Health Criteria 134 Cadmium International Programme on Chemical Safety (IPCS) Monograph, 1992.

15. Lars J Hazards of heavy metal contamination. Department of Epidemiology and Public Health, Imperial College, London, UK. British Medi. Bull 2003; 68: 167182.

16. Jarup L, Berglund M, Elinder CG, Nordberg G, Vahter M Health effects of cadmium exposure- a review of the literature and a risk estimate. Scand J work Health 1998; (Suppl 1): 1-51.

17.Staesen JA, Roels HA, Emelianov D, Kuznetsova T, Thijs L, Vangronsveld J Environmental exposure to cadmium, forearm bone density, and risk of fractures: Prospective population study. Public Health and Environmental Exposure to Cadmium (PheeCad) Study Group. Lancet 1999; 353: 1140-4.

18. Nordberg G, Jin T, Bernard A, Fierens S, Buchet JP, Ye T, Kong Q, Wang $\mathbf{H}$ Low bone density and renal dysfunction following environmental cadmium exposure in China. Ambio 2002; 6: 478-81.

19. Nishijo M, Nakagawa H, Morikawa Y, Tabata M, Senma M, Miura K. Mortality of inhabitants in an area polluted by cadmium: 15 year follow up. Occup. Environ. Med.1995; 52: 181-4.

20. Wright RO, Tsaih SW, Schwartz J, Wright RJ, Hu H Association between iron deficiency and blood lead levels in a longitudinal analysis of children followed in an urban primary care Clinic. J Pediar 2003: 142: 710-713.

21. Clark N, Royal J, Seeler R Interaction of iron deficiency and lead and the hematologic findings in children with severe lead poisoning. Pediatrics 1988: 81: 247-254.

22.Elizabeth VME, Kvalsvig JD, Faber M, Kruger M, Kenoyer DG, Benade AJS Effect of iron, iodine, and B-carotene-fortified biscuit on the micronutrient status of primary school children: a randomized control trial, Am. J. Clin, Nutr. 69, 497503 (Erratum in Am. J. Clin. Nutr. (1999): 69, 1294).

23. Nieuwenhuize J, Poley-vos CH, Van Den Akker AH, Van Delft W Comparison of microwave and conventional extraction techniques for the determination of metals in soils, sediment and sludge samples by atomic spectrometry. Analyst 1991; 116:347-351. 
24.Smith JC, Butrimovitz GP, Purdy WC. Direct measurement of Zinc by atomic absorption spectroscopy. Clin. Chem. 25:1487, 1979.

25. Vercoutere K, Fortunati U, Muntau H, Griepink B, Maier EA The certified reference materials CRM 142 light sandy soil. CRM 143 R Sewage sludge amended soil and CRM 145 sewage sludge for quality control in monitoring environmental and soil pollution. Fres: J. Anal Chem. 1995; 352:197-202.

26. Moore PD, Chapman SB Methods in plant Ecology. Blackwell scientific publication, Oxford, London 1986.

27. SAS. Institute Inc SAS/STATUser'sGuide, version 8, Cary, NC.1999.

28. Pozebon D, Dresler VL, Curtius AJ Quim, Rothenberg SJ, Poblano A, Schnaas L Brainstem auditory evoked response at 5years and prenatal lead exposure. Neurotoxicol Teratol. 2000; 22:503-510.

29. Bentlin FR, Pozebon D, Mello PA, Flores EM Determination of trace elements in paints by direct sampling graphite furnace atomic absorption spectrometry. Anal Chim Acta. 2007 Oct 17; 602(1):23-31. Epub 2007 Sep 6.

30. Oxley JC, Smith JL, Kirschenbaum LJ, Marimganti S, Vadlamannati S Detection of explosives in hair using ion mobility spectrometry. J Forensic Sci. 2008 May;53(3):690-3.

31. Freeland-Grave JH, Hendrickson PJ, Ebangit ML, Snowden JY Salivary zinc as an index of zinc status in women fed a low-zinc diet. Am J Clin Nutr 1981; 43:312-21.

32. Connie WB, Jeanne HFG, Susan A, Fare B, Rebecca SP, Jacqueline JF, Patti G Zinc, magnesium, copper, and protein concentrations in human saliva: age and sex-related differences. Am J. Clin Nutr 1990; 51: 462 - 9.

33. Bellinger D, Liveton A, Alfred B, Rarinowitz M Postnatal lead exposure and behavioral problems in school age children. Environmental Research. 1994; 66:12-30.

34. Wasserman GA, Musarigovic A, Liu X, Eline I, Factor-Litvac P, Craziano JH Lead exposure and motor functioning in 4-5years old children. The Yugoslavia prospective study. Journal of Pediatrics 2002; 137:555-61.

35. Hernandez-Avila M, Peterson KE, Gonzalez-Cossio T, Sanin LH, Aro A, Schnaas L, Hu H Effect of maternal bone lead on length and head circumference and birth. Arch Environ Health 2002; 57: 482 - 488. 